\title{
EKOKRITIK SASTRA DALAM PUISI TALANG DI LANGIT FALASTIN KARYA DHENI KURNIA
}

\author{
Qori Islami Aris \\ Universitas Lancang Kuning, Pekanbaru \\ qoriislamibintiaris@unilak.ac.id
}

\begin{abstract}
One of the literary works is poetry. Poetry can be a medium for poets to convey ideas, concepts and thoughts. One of these ideas and thoughts is based on the observations of the environment. It implies that poetry is also related to other fields of study. One of the fields of study that can be related to literary works is ecocriticism. Ecocritics is focused on the relationship between literature and the environment or how the relationship between humans and their physical world are reflected in literary works. In this study, the writer tries to analyze the poetry Talang di Langit Falastin written by Dheni Kurnia through the concept of echocritics as an analytical lens. The result of this study shows that Talang di Langit Falastin illustrates environmental exploitation and pollution caused by political and economic factors. This poem becomes interesting because the poet analogized Talang Mamak and Palestine which are equally oppressed, causing environmental destruction and exploitation. The destruction of the environment in Palestine was caused by the Zionist invaders who bombarded with bombs and nuclear weapons, while the environmental destruction in Talang Mamak was carried out by capitalists who burned forests to open the new land for economic interests that affected the misery of living things in the environment.
\end{abstract}

Keywords: Ecology, Ecocriticism, Literary Work, Poetry

\section{PENDAHULUAN}

Puisi, sebagai salah satu bentuk karya sastra dalam bentuk pemikiran atas sebuah gagasan, dapat menjadi media bagi pengarang untuk menyampaikan berbagai hal yang dianggap penting untuk diketahui oleh masyarakat. Sebuah puisi diciptakan tidak hanya fokus pada aspek keindahan bentuk semata, namun juga perlu memperhatikan makna yang disajikan.

Di dalam bentuk karya sastra yang baik, akan ditemui unsur-unsur 
pengetahuan lain atau interdisiplin ilmu, seperti sains, filsafat, sosial, hukum, psikologi, ekologi, dan lain sebagainya. Seperti yang dikemukakan oleh Semi (1988:19) bahwa karya sastra banyak terkait dengan bidang ilmu pengetahuan yang lain.

Ekokritik sastra merupakan fenomena baru dalam studi sastra dan kajian sastra. Ekokritik berkaitan dengan hubungan antara sastra dan lingkungan atau bagaimana hubungan manusia dan lingkungan yang tercermin dalam sastra atau karya sastra. Menurut Johnson (2009:7-12), over the last three decades, it has emerged as a field of literary studi that addresses how human relate to nonhuman nature or environtment in literature.

Istilah ekokritik muncul untuk pertama kalinya dalam esei William Rueckert yang berjudul Literature and Ecology: An Experiment in Ecocriticism pada 1978. Dalam esei ini, Rueckert berpendapat bahwa kritik sastra harus membahas ekologi. Sebelumnya, pada 1974, esei Josef W. Meeker berjudul The Comedy of Survival: Studies in Literary Ecology dianggap benih awal di mana ekokritikisme diciptakan dalam kajian sastra. Penggunaan istilah "Literary Ecology" dalam esei Meeker tersebut menunjukkan bahwa penggunaan ekokritik oleh Rueckert dalam makna ganda sebagai studi tentang tema biologis dan hubungan yang muncul dalam karya sastra dan upaya untuk menemukan peran vital yang telah dimainkan oleh keduanya; sastra dan ekologi spesies manusia.

Adanya bidang ilmu ekologi sastra tersebut menunjukkan bahwa puisi, sebagai salah satu bentuk karya sastra, dapat berkaitan dengan alam sekitar. Penyair dapat mengeksplorasi alam serta lingkungan yang ada di sekitarnya sebagai sebuah inspirasi atau sebagai sebuah media untuk menyalurkan gagasan-gagasan atau pesan-pesan tertentu kepada pembaca atau masyarakat. Salah satu puisi yang menggunakan 
Jurnal Ilmu Budaya, Vol. 16, No. 2 Februari Tahun 2020

kearifan lokal alam sekitar adalah puisi Talang di Langit Falastin karya Dheni Kurnia.

\section{EKOLOGI DAN EKOKRITIK SASTRA}

Ekokritik berasal dari Bahasa Inggris yakni ecocriticism yang terbentuk dari dua kata ecology dan criticism. Ekologi dimaksudkan sebagai kajian ilmiah mengenai hubungan-hubungan makhluk hidup (manusia, hewan, dan tumbuhan) terhadap satu dengan yang lain dan terhadap lingkungannya. Sedangkan kritik dapat dimaknai sebagai salah satu bentuk ekspresi penilaian terkait baik atau buruk sesuatu hal. Sederhananya, ekokritik dapat dipahami sebagai kritik yang berorientasi pada lingkungan.

Munculnya ekokritik dianggap sebagai salah satu perkembangan yang cukup signifikan dalam kajian dan kritik sastra. Glotfelty (1996) dalam Introduction to the Ecocriticism Reader: Landmarks in Literary Ecology berpendapat "ecocriticism has been predominately a write movement. It will become a multi-ethnic movement when stronger connections are made between the environtment and issues of social justice and when a diversity of voices are encouraged to contribute to the discussion" (p.xxv). Pendapat ini menyoroti tentang pentingnya membuka bidang ekokritik untuk memasukkan lebih banyak teks-teks etnis dan penulis-penulis dari seluruh penjuru dunia. Dalam buku ini juga, sejumlah pertanyaan diajukan oleh Glotfelty yang berkaitan dengan ekokritik, antara lain; Bagaimana alam direpresentasikan dalam soneta? Bagaimana ilmu pengetahuan terbuka terhadap analisis sastra? Apa manfaat timbal balik antara kajian sastra dan wacana lingkungan dalam interdisiplin ilmu seperti sejarah, psikologi, sejarah seni dan etika?

Ekokritik juga menguraikan dan menyuarakan dampak destruktif dari perkembangan teknologi 
terhadap alam dan lingkungan.

Ekokritik merupakan salah satu

kajian sastra yang mewakili tidak

hanya alam, tapi juga budaya dan

masyarakat, dan merupakan

pendekatan teoritis untuk

keterkaitan alam, budaya, dan terkadang unsur mitos. Buell

(1995:11) menyatakan "ecocriticism has a triple duty, the scientific study of nature, the scholarly analysis of cultural representations, and the political struggle for more sustainable ways of inhability the natural world".

Untuk dapat dikatakan sebagai ekokritik sastra, Lawrence Buell menyoroti beberapa kriteria, antara lain; (1) lingkungan non-human hadir tidak hanya sebagai sebuah bingkai tetapi sebagai kehadiran yang menunjukkan bahwa sejarah manusia diimplikasikan dalam sejarah alam; (2) kepentingan manusia tidak dipahami sebagai satu-satunya kepentingan yang sah (legitimate); (3) akuntabilitas manusia terhadap lingkungan merupakan bagian dari orientasi etis teks, dan (4) beberapa pengertian lingkungan adalah sebagai suatu proses bukan sebagai pengertian yang konstan atau suatu pemberian yang paling tidak tersirat dalam teks (Buell, 1995: 7-8).

Dari pemaparan-pemaparan di atas, dapat disimpulkan bahwa alam dan lingkungan hidup, tidak hanya dipahami sebagai latar tempat dan suasana yang dimanfaatkan dalam pembuatan setting dan plot pada sebuah karya sastra, akan tetapi juga merupakan unsur yang ikut membangun estetika dan makna pada sebuah karya sastra. Alam dan lingkungan hidup merupakan wilayah kajian dalam ilmu sastra, khususnya dengan menggunakan perspektif ekokritik.

\section{PEMBAHASAN}

\section{A. Latar Sosiohistoris Pengarang}

Dheni Kurnia, yang lahir di Airmolek, Indragiri Hulu Riau, 5 Mei 1962, adalah wartawan, budayawan dan penyair Indonesia 
asal Riau. Sudah menerbitkan 5

buku puisi tunggal, 11 buku non

fiksi termasuk catatan perjalanan

jurnalistik, serta 23 Antologi Puisi

bersama penyair di Indonesia

lainnya. Menamatkan pendidikan di

Fakultas Keguruan Jurusan Bahasa

dan Sastra Indonesia dan Magister

Publisistik. Dheni sering

membacakan puisinya keliling

Indonesia dan beberapa negara di

luar negeri. Dheni bermukim di

Pekanbaru dan sehari hari adalah

Editor in Chief (Pemimpin Redaksi)

di Surat Kabar Harian Vokal.

Pengalamannya sebagai wartawan perang di Palestina mengetuk hatinya untuk menulis puisi yang berjudul Talang di Langit Falastin, yang juga tidak terlepas dari unsur lokal.

B. Struktur Fisik dan Batin yang Membangun Puisi Talang di Langit Falastin Karya Dheni Kurnia

Talang di Langit Falastin
Aku melihat talang di langit Falastin penuh hutan yang terbakar hangit tulang hangus melepuh airmata bercampur dengan nanah sungai penuh aliran darah nafas lenguh didera sesak jantung mati tak berdetak diam bersama gulungan angin

Aku menghirup debu Falastin menelan bau dan asap mesiu mata menyebak dalam genangan dada menyesak menahan amarah alir nadi tak lagi menderas luluh lantak tak bersisa menyentak sengat ke ubun-ubun menimbun dendam sepanjangnya

Tak ada yang tersisa di falastin selain remah dan anyir darah seperti hutan di tanah talang porak poranda ditindas kekuasaan tak ada lagi tempat bermain marwah tergadai di ujung senjata tinggal memandang tinggal mengenang

Aku melihat talang di langit falastin tertimbun lumpur dan tanah hitam berbalut kafan di setiap simpang hanyut gelimpang di teluk syria tersandar kaku di jalur gaza 
Jurnal Ilmu Budaya, Vol. 16, No. 2 Februari Tahun 2020

bertimbun mayat hingga ke
kanaan
Ketika talang dijarah Indragiri
padi tak menguning
damar tak menjadi
malam berpanas hinggakan
pagi
sejak Falastin mengangkat
wajah
Yahudi memaki Bani Umayyah
Abbasiyah tunduk dalam
ancaman
Suriah dan Yerusalem berdiam
diri
tak ada lagi kata yang benar
tak ada lagi tempat menyembah
luluh lantak dimakan barah
Talang di langit Falastin
bagai menulis sejarah panjang
sejak peradaban Mesir dan
Bani Israil
sejak takluk ke Babilonia dan
Parsi
sejak Yunani dan Romawi
berkuasa
sejak Kekhalifahan
Fatimiyah dan Syi'ah
hingga ke pemerintahan Turki
Utsmani
engkau bernafas di bumi biadap
Talang dan Falastin
langitmu penuh kotoran
bumimu tergadai kekuasaan
tubuhmu ringkih
menyapih ditelan tirani
padahal engkau memiliki
marwah yang tinggi
sejarah yang panjang
bangsa yang penuh peradaban

Talang di langit Falastin menggantung di angin bergulung menangis dalam cengkram Zionis! Gaza, 1992.

\section{1) Struktur Fisik pada Puisi}

\section{a. Diksi}

Diksi merupakan pilihan kata yang dipilih oleh pengarang agar karya yang disajikan lebih menarik dari segi kata-kata. Diksi yang digunakan pada puisi ini cenderung mengacu pada makna denotasi, namun ada beberapa kata atau kalimat yang bermakna konotasi, misalnya airmata bercampur dengan nanah yang bermakna kesedihan yang teramat dalam seperti kematian orang-orang yang disayangi, atau kehilangan sesuatu yang sangat berharga, menelan bau dan asap mеsiu bermakna bahwa sering mengalami peristiwa di mana bom atau bahan peledak lainnya dijatuhkan di tempat tersebut, menyentak sengat ke ubun-ubun bermaksud bahwa tak sanggup 
berpikir jernih atau tak tahu apalagi yang dilakukan.

\section{b. Imaji}

Imaji yaitu susunan kata-kata yang dapat mengekspresikan pengalaman indrawi, seperti penglihatan, penciuman, pendengaran, dan perasaan. Imaji penglihatan terdapat pada kalimat;

Aku melihat Talang di Langit Falastin/ Penuh hutan yang terbakarl Aku melihat Talang di Langit Falastin/ Tertimbun lumpur dan tanah hitam/ Berbalut kafan di setiap simpang/ Hanyut gelimpang di teluk Syirial Tersandar kak di Jalur Gazal Bertimbun mayat hingga ke Kan'aan/

Imaji Pendengaran terdapat dalam kalimat;

Jantung mati tak berdetak.

Diam bersama gulungan angin.

Imaji penciuman terdapat dalam kalimat;

Aku menghirup debu Falastin.

Menelan bau dan asap mesiu.
Imaji perasaan terdapat dalam kalimat:

Mata menyebak dalam genangan/ Dada menyesak menahan amarah/Menimbun dendam sepanjangnyal Marwah tergadai di ujung senjatal Tinggal memandang tinggal mengenang/

\section{c. Bahasa Figuratif}

Bahasa figuratif dikenal juga dengan istilah majas. Ada beberapa majas yang ditemukan dalam puisi ini.

Majas personifikasi, antara lain;

Sejak Falastin mengangkat wajah.

Yahudi memaki Bani

Umayyah.

Suriah dan Yerussalem berdiam diri.

Bagai menulis sejarah panjang.

Engkau bernafas di bumi biadab.

Menggantung di angin bergulung.

Menangis dalam cengkraman Zionis.

Majas Hiperbola, antara lain:

Hangit tulang hangus melepuh/ Airmata bercampur dengan nanah/ Sungai penuh aliran darah/ 
Alir nadi tak lagi menderas/ Tak ada yang tersisa di Falastin selain remah dan anyir darah/ Porak poranda ditindas kekuasaan/ Tak ada lagi tempat bermain/

\section{2) Struktur Batin pada Puisi}

\section{a. Tema}

Tema pada puisi ini mengangkat isu-isu kemanusiaan, khususnya isu kemanusiaan tentang Palestina dan Talang Mamak. Puisi ini menggambarkan kerisauan penyair menyaksikan keadaan sebuah negara/ daerah yang penuh dengan konflik dan perang.

\section{b. Suasana}

Suasana yang tergambar
dalam puisi tersebut adalah
menyedihkan dan mengharukan. Hal ini ditunjukkan pada bait 1,2, 3, dan 4 pada puisi tersebut. Penyair menggambarkan sebuah tempat yang porak poranda akibat perang, di sisi lain, penyair juga teringat akan kampung halamannya yaitu Daerah Talang Mamak yang juga terkikis modernisasi akibat kapitalis. Ke dua tempat ini memang memiliki kondisi fisik yang jauh berbeda, akan tetapi titik fokus penyair dalam hal ini adalah ke dua negeri ini sama-sama menderita akibat penjajahan, zionis dan kapitalis. Perasaan takut, cemas, dan dendam menjadi hal yang tak bisa dipungkiri yang tercermin dalam untaian kalimat berikut; alir nadi tak lagi menderas / luluh lantak tak bersisa / menyentak sengat ke ubun-ubun / menimbun dendam sepanjangnya.

\section{c. Amanat}

Berkenaan dengan tema yang mengangkat isu kemanusiaan, amanat yang terkandung dalam puisi ini adalah perlunya menjaga persatuan dan kesatuan, meningkatkan rasa kepedulian pada saudara-saudara yang tertindas dengan tidak memandang ras, suku, agama, dan bangsa.

\section{Ekokritik pada Puisi Talang di Langit Falastin Karya} Dheni Kurnia

\section{Bait 1}


Jurnal Ilmu Budaya, Vol. 16, No. 2 Februari Tahun 2020

Aku melihat talang di langit falastin penuh hutan yang terbakar hangit tulang hangus melepuh airmata bercampur dengan nanah sungai penuh aliran darah nafas lenguh didera sesak jantung mati tak berdetak diam bersama gulungan angin

Pada bait 1 puisi di atas, penyair menggambarkan kondisi di Palestina. Pada bait pertama ini penyair menarasikan tentang keadaan Palestina yang dipenuhi dengan mayat yang hangus terbakar. Lingkungan Palestina yang sudah tidak asri lagi sebab tanah bersih sudah dipenuhi darah mayat yang bergelimpangan, sungai yang berubah warna menjadi merah bermaksud sungai yang tidak lagi bisa dimanfaatkan airnya sebagai sumber kehidupan akibat tercemar darah manusia dan bangunan yang hancur akibat bom. Hal ini dianalogikan seperti areal lingkungan hutan suku Talang Mamak yang sebagian besar terbakar akibat pembakaran hutan untuk membuka lahan baru.

\section{Bait 2}

Aku menghirup debu falastin menelan bau dan asap mesiu mata menyebak dalam genangan

dada menyesak menahan amarah alir nadi tak lagi menderas luluh lantak tak bersisa menyentak sengat ke ubunubun menimbun dendam sepanjangnya

Pada bait kedua juga menggambarkan keadaan udara Palestina yang sudah tercemar akibat asap mesiu bom yang meluluhlantakkan Palestina. Dan perasaan sang penyair yang dipenuhi kesedihan, kedukaan yang mendalam sampai ke ubun-ubun hingga menyisakan dendam. Hal ini dianalogikan dengan kondisi lingkungan di daerah Talang yang sudah sangat tercemar dan terpolusi akibat pembakaran hutan, udara yang tak lagi sehat akibat asap. Kecintaan penyair pada Talang cukup terlihat karena kesedihan dan kemarahan akibat pengrusakan 
lingkungan di daerah Talang yang notabene adalah tempat kelahiran sang penyair.

\section{Bait 3}

tak ada yang tersisa di falastin

selain remah dan anyir

darah

seperti hutan di tanah talang porak poranda ditindas

kekuasaan

tak ada lagi tempat bermain marwah tergadai di ujung senjata

tinggal memandang tinggal mengenang

Pada bait ketiga menggambarkan keadaan Palestina yang luluh lantak hingga hampir memusnahkan seluruh bangunan dan menewaskan banyak orang, yang tercium adalah bau darah manusia yang tewas akibat bom. Sama seperti lingkungan hutan di Talang Mamak, hewan-hewan banyak mati, orang-orang suku Talang Mamak kehilangan tempat mencari makanan, kayu, dan obatobatan akibat hutan yang dibakar. Hanya tinggal memandang dan mengenang.

\section{Bait 4}

Aku melihat talang di langit Falastin

tertimbun lumpur dan tanah hitam

berbalut kafan di setiap simpang hanyut gelimpang di Teluk Syria tersandar kaku di Jalur Gaza bertimbun mayat hingga ke Kan'aan

Pada bait ini, penyair menggambarkan hutan Talang Mamak seperti Palestina yang telah tertimbun lumpur dan tanah hitam bekas terbakar. Keadaan Palestina kini yang dipenuhi mayat yang telah dikafani, ada juga beberapa mayat yang hanyut hingga ke Teluk Syria, ada pula yang tak lagi bisa dikenali hingga terbiarkan di Gaza dan di Kan'aan

\footnotetext{
Bait 5 dan 6

ketika talang dijarah indragiri padi tak menguning damar tak menjadi malam berpanas hinggakan pagi sejak falastin mengangkat wajah yahudi memaki bani umayyah abbasiyah tunduk dalam ancaman
} 
Jurnal Ilmu Budaya, Vol. 16, No. 2 Februari Tahun 2020

suriah dan yerusalem
berdiam diri
tak ada lagi kata yang benar
tak ada lagi tempat
menyembah
luluh lantak dimakan barah
talang di langit falastin
bagai menulis sejarah
panjang
sejak peradaban mesir dan
bani israil
sejak takluk ke babilonia dan
parsi
sejak yunani dan romawi
berkuasa
sejak kekhalifahan
fatimiyah dan syi'ah
hingga ke pemerintahan
turki utsmani
engkau bernafas di bumi
biadap

Pada bait kelima dan keenam, penyair ingin menyampaikan dari sisi historis ketika suku Talang Mamak dijajah oleh Kerajaan Indragiri, warga suku Talang Mamak harus menyerahkan upeti dari hasil panen padi dan getah damar sebagai bentuk eksploitasi lingkungan hidup. Dianalogikan ketika Palestina dimasuki oleh Yahudi sejak zaman Bani Umayyah hingga Turki Utsmani, Palestina terus terjajah.

\author{
Bait 7 dan 8 \\ Talang dan falastin \\ langitmu penuh kotoran \\ bumimu tergadai kekuasaan \\ tubuhmu ringkih \\ menyapih ditelan tirani \\ padahal engkau memiliki \\ marwah yang tinggi \\ sejarah yang panjang \\ bangsa yang penuh \\ peradaban \\ talang di langit falastin \\ menggantung di angin \\ bergulung \\ menangis dalam cengkram \\ zionis!
}

Pada bait 7 dan 8 ini, penyair menggambarkan kondisi Palestina dan Talang Mamak yang kini memprihatinkan akibat penjajah. Dua daerah yang sangat berjauhan jaraknya, namun memiliki kenestapaan yang sama, lingkungan yang asri dan indah, sudah hanya menjadi kenangan akibat eksploitasi Zionis dan Kapitalis demi kepentingan politik dan ekonomi.

\section{SIMPULAN}

Puisi Talang di Langit Falastin karya Dheni Kurnia lugas, tegas, dan apa adanya. Metafora yang digunakan metafora yang 
'terang' dan 'dekat' sehingga apa yang ingin disampaikan puisi tersebut dapat dengan mudah dipahami pembaca dan mampu menyentuh perasaan kemanusiaan mereka.

Penganalogian aspek kehidupan suku Talang Mamak dengan Palestina menjadi bagian yang sempurna untuk menumbuhkan kesan kesedihan yang teramat dalam. Nilai histori pada puisi tersebut membuat kedua sudut pandang ini antara Talang Mamak dan Palestina menjadi apik untuk disandingkan.

Eksploitasi lingkungan pada puisi ini dideskripsikan secara jelas dan gamblang oleh penyair. Kebakaran hutan, eksploitasi hasil pertanian dan perkebunan, hingga ke areal lingkungan masyarakat bertempat tinggal. Begitu juga penganalogian terhadap Palestina, dengan gambaran porak porandanya Palestina berdampak pada lingkungan yang tak layak lagi untuk dihuni sebab polusi yang dihasilkan oleh senjata nuklir atau sejenisnya bukan tak mungkin akan berdampak puluhan hingga ratusan tahun. Kisah ini mengingatkan kita pada kota Hiroshima dan Nagasaki saat dibombardir oleh sekutu.

\section{DAFTAR PUSTAKA}

Buell, Lawrence. 1995. The Environmental Imagination. Cambridge: Harvard University Press.

Glotfelty \& Fromm. 1996. The Ecocriticism Reader: Landmarks in Literary Ecology. Athens: University of Georgia Press.

Johnson L. 2009. Greening the Library: The Fundamentals and Future of Ecocriticism in http://www.asle.org/assets/doc s/Ecocriticism_essay.

Kaswadi. 2015. Paradigma Ekologi dalam Kajian Sastra. Jurnal Paramasastra. Surabaya: Universitas Negeri Surabaya Volume 2 Nomor 2.

Keraf, Gorys. 2008. Diksi dan Gaya Bahasa. Jakarta: Gramedia Pustaka Utama.

Waluyo, Herman J. 2002. Apresiasi Puisi. Jakarta: Gramedia Pustaka Utama. 